\title{
Review of Ernesto Screpanti's Labour and Value: Rethinking Marx's Theory of Exploitation. Cambridge: Open Book Publishers, 2019, 131 pp.
}

\author{
NICHOLAS VROUSALIS \\ Erasmus University Rotterdam
}

In this succinct, lucid, and well-argued book, Ernesto Screpanti sets out to reconsider Marx's categorial framework of value and exploitation.

Screpanti argues for the following claims. First, labour under capitalism is coextensive with the subsumption of labour to capital. By implication, Marx's categories of value and 'abstract labour' represent the exercise of the workers' set of productive capacities, subsumed under the capitalist firm as its own. According to Screpanti, it follows that abstract labour is not a substance or 'natural abstraction', as some Marxists maintain. It is, rather, a social relation of subordination: "the price of [the worker's] freedom" (44), sold to the owner of the means of production for a wage. Second, capitalist exploitation presupposes this subordination of the worker to the capitalist through the capitalist's control over the surplus product. This product, says Screpanti, is a measure of 'overwork', that is, a measure of how much longer workers must work to produce their own subsistence, compared to the counterfactual in which they organize their own production. Third, according to Screpanti, Marx's critique of capitalist exploitation is not a moral or ethical critique; it is, rather, a critique of overwork from the point of view of the oppressed, "an interpretation of the workers' sentiments" (98).

Screpanti offers cogent arguments for the first two claims. I will argue that the second claim is substantively correct: capitalist exploitation presupposes capitalist control over the labour process and is expressed in capital's extraction of a surplus product. However, Screpanti's defence of the first claim is not, as it stands, acceptable. For the capitalist mode of exploitation does not require wage-labour or the existence of the capitalist factory. All it requires is that capital has enough control over the labour process to allow surplus extraction. Screpanti, in other words, misidentifies capital's mode of exploitation with its mode of production. Moreover, Screpanti's third claim is false, indeed incoherent. If capitalist exploitation expresses the subordination of the worker, as Screpanti argues, then 
the term 'subordination' in that conditional must have a moral, and not purely descriptive, meaning.

\section{VALUE AND ABSTRACT LABOUR}

Marx begins volume one of Capital by introducing Adam Smith's distinction between use- and exchange-value. By way of an explanation of the latter, he introduces a further distinction between concrete and abstract labour: the useful, creative, object-directed labour of "the joiner, the mason or the spinner" (Marx 1976, 128), versus that labour that has lost its determinate, content-driven character and is exclusively directed towards the production of commodities. As values, commodities only express "human labour in the abstract” (ibid.). This conceptual manoeuvre has baffled commentators. Some of them have been tempted by the idea that abstract labour is a trans-historical, 'natural' category that would feature in any commodity-producing society, both pre- and post-capitalism.

Screpanti spends chapter 1 of his book criticizing this theory. Chapter 2 provides an alternative interpretation of abstract labour. According to Screpanti, the employment contract is

an agreement whereby workers take on an obligation to obey their employers. [...] With the employment contract, a worker renounces his decision-making freedom in the labour process by entering into a relationship of subordination to the capitalist. This enables capital to subsume workers' capacities and use them to secure surplus value. [...] Here, abstract labour is no longer a natural object. Rather, it emerges from a historically determined social relationship. By virtue of this characteristic, it turns out to coincide with the time spent by the wageworker in the production process. (31)

This alternative interpretation undermines the naturalistic account of abstract labour-a hangover from Hegel's notion of a "contract for services" (32) - which takes worker productivity to be exogenously determined. Consider, for example, this characteristic passage from Capital:

In order to be able to extract value from the consumption of a commodity, our friend, Moneybags, must be so lucky as to find, within the sphere of circulation, in the market, a commodity, whose use value possesses the peculiar property of being a source of value, whose actual consumption, therefore, is itself an embodiment of labour, and, consequently, a creation of value. The possessor of money does find on the market such a special commodity in capacity for labour or labour power. (Marx and Engels 2010, 177) 
Passages like this make the worker look like the proverbial golden-egglaying goose: the capitalist purchases the commodity labour power, a natural capacity of the worker to produce value-added greater than what she receives as remuneration. The exercise of that capacity is the source of profit and of surplus value. Screpanti argues that this fundamentally misdescribes the nature of the relationship between capital and labour (31ff.).

Screpanti is right: workers are not golden-egg-laying geese, whose productivity remains constant wherever you put them. Rather, what enables the capitalist to extract surplus value from the worker is that productivity is endogenously determined, such that the capitalist can increase the duration and intensity of work to levels that will, in general competitive equilibrium, avail her of surplus value. So abstract labour is not a natural or monadic substance that will tend to manifest itself under any set of commodity-producing arrangements, but a relational property coextensive with the subordination of labour to capital. This makes the wage "the price of freedom, a payment for obedience, and not the value of a commodity" (44).

\section{The NATURE OF SUBSUMPTION}

Screpanti's claim that labour becomes abstract-losing its determinate content-just when its performance becomes the exercise of capital's own capacity is plausible. In chapter 3 of his book, Screpanti makes a strong case for the claim that capitalist exploitation is the extraction of surplus labour based on that control, such that abstract labour and capitalist exploitation are coextensive. But what does it mean for capital to 'control' labour and the labour process? ${ }^{1}$ Screpanti thinks 'control' presupposes the capitalist mode of production, that is, the capitalist wage-labour-employing factory. Yet, by Screpanti's own admission, this characterization is too strong. There are cases, he says, where

capitalist exploitation takes place through homeworking or subcontracting to formally self-employed workers. In many of these cases, the main contractor or the contracting administrator maintains a certain power in determining the labour process and controlling the contractors. Benetton, a company that makes wide use of a modern form of the putting-out system, provides a typical example. [...] In yet other cases, the workers are exploited by means of contracts for services in

\footnotetext{
${ }^{1}$ Marx discusses the 'subsumption' of labour to capital and the worker's concomitant 'subordination' to her capitalist boss in Marx (1976, 411ff.), and in Marx and Engels (1962, 199, 377, 533; 2010, 302, 314, 422, 426).
} 
which the service buyer uses market power to appropriate surplus value. In some such cases, exploitation takes place through a mix of labour subsumption and capitalist market power. (52)

But then capitalist exploitation does not presuppose capitalist production: capital can exploit labour without wage-labour. To borrow from Marx's own discussion of usury capital, Screpanti's examples have "capital's mode of exploitation without its mode of production" (Marx 1981, 732). In response, Screpanti distinguishes between the appropriation and the production of surplus value. He contends that "subordination, as established by an employment contract, is a necessary condition for the production of surplus value" (52).

Marx denies this. In chapter 36 of volume three of Capital, for example, he distinguishes between two forms of usury: lending money to "extravagant magnates" for the consumption of luxuries and lending to "small producers who possess their own conditions of labour" (1981, 729). The latter form of usurer's interest, he suggests, represents new surplus value. ${ }^{2}$

Consider this schematic reconstruction of Screpanti's argument:

(1) Abstract labour entails capitalist control over the labour process.

(2) Capitalist control over the labour process entails the subsumption of labour to capital.

(3) The subsumption of labour to capital entails wage-labour.

If all of (1)-(3) hold, then it follows that abstract labour entails wage-labour-the labour market. Screpanti thinks this is both a reasonable interpretation of Marx and a sound argument in its own right. I will discuss the interpretation of Marx, first, and the soundness of the argument, second.

In previous work, I have argued that Marx vacillates about (2) (Vrousalis 2018; see also Skillman 2007, which inspired that argument). In volume one of Capital, Marx affirms (2), construing subsumption exhaustively as either 'formal' or 'real'. However, in volume three, he introduces the idea of 'hybrid' subsumption to deal with antediluvian forms

\footnotetext{
${ }^{2}$ Screpanti also cites Gilbert L. Skillman as providing evidence that supports the necessity of wage-labour for the production of surplus value. But Skillman does nothing of the sort; indeed, he explicitly contradicts Screpanti's contention: "Marx is careful to distinguish cases such as this, in which circuits [of interest-bearing and merchants' capital] served only to redistribute existing values, from cases in which these circuits financed new commodity production" (Skillman 2019, 13ff.).
} 
of capital-usury and merchant capital. Construed inclusively, (2) accommodates these circuits of capital as forms of subsumption proper. But then (3) is false, for hybrid subsumption excludes wage-labour.

Now, whatever Marx thought, (2) must be inclusively construed. That is, there is no reason to assume that antediluvian forms of capital cannot help produce new commodities, new value, and new surplus value; Marx's own examples show that these forms can produce new value, not merely redistribute existing value. But then capital can control the labour process without subsuming it, whether 'formally' or 'really', under the capitalist factory. It follows that (3) is false and the deduction of wage-labour from abstract labour is invalid.

Note that this conclusion is compatible with (1): the capitalists might, for example, control labour indirectly, by lending their capital only to those worker-owned firms that engage in production that the capitalists are willing to finance. ${ }^{3}$ This is another way one gets capitalist exploitation without capitalist production. Indeed, this is all that Screpanti needs to vindicate his anti-naturalist conception of abstract labour as labour subsumed under capital and therefore ostensibly performed as an exercise of capital's own capacity.

\section{FREEDOM AND EXPLOITATION}

The weakest part of the book is Screpanti's discussion of the ethics of exploitation, especially in the introductory and concluding chapters. His book is replete with references to 'freedom', 'free associated labour', 'freedom of choice', 'control over surplus and labour process', 'labour subjection', 'worker subordination', and 'capital's despotism'. This is, for example, Screpanti's interpretation of Marx's famous 'tanning of the hide' passage:

Behind the ideological construal of the circulation process, a worker turns out to be 'like someone who has brought his own hide to market and now has nothing else to expect but a tanning'. 'The tanning of a hide' is a metaphor hinting at what happens in the production process, where workers are compelled to work hard under the capitalist's command. In this way, the labour exchange is unmasked as the legal and ideological institution by which capital coaxes workers to accept

\footnotetext{
${ }^{3}$ The hiring of capital by labour preserves the fetishistic fissure between the capitalist appearance (of free and equal transactors) and the reality (of worker subordination). It follows that worker control over the workplace does not guarantee that the workers are calling the shots (see, among others, Cohen 1989; and Vrousalis 2019).
} 
the subordination relationship as if it were a commodity exchange. (94)

So far, so good. But then Screpanti adds that this is merely a "descriptive" proposition (95), one that "brings to the fore an alternative class viewpoint" (94), and which is "an interpretation of the workers' sentiments" (98). These suggestions are inconsistent both with the tenor and the content of Screpanti's arguments. In terms of the general tenor of his argument, the Screpantian 'subordination' of the worker cannot be generically equivalent to, say, the 'subordination' of the buttress to the wall or the 'subordination' of the spindle to the wheel. For if it were, then the workers would have no reason to resist it, indeed there would be no normative fact of the matter justifying a revolution to overthrow subordination altogether. ${ }^{4}$ The workers' claim to revolution would be as nought-as strong as the claim of the bourgeoisie to suppress it. ${ }^{5}$

I will not pursue these thoughts further: they have received extensive defence elsewhere (see Cohen 2000; and Geras 1986). There is, however, an important truth in Screpanti's critique of justice $(6,7,78)$. Although Marx grounds his critique of capitalism on an account of freedom, he does criticize Pierre-Joseph Proudhon and other socialists of his time for their theories of distributive justice. Marx's suggestion, influentially reconstructed by Allen Wood (1972), is that distribution is a necessary consequence of the mode of production, which mobilizes, in addition, a set of putative justifications for that distribution. Wood's thesis, if true, would suffice to indict some of these putative justifications as ideological. ${ }^{6}$

But it does not follow, and it is false, that Marx does not need a set of objective moral standards by which to criticize capitalist exploitation. If those features of capitalist production that make it appear as a system of equality and freedom "prove to be inequality and unfreedom" (Marx 1973, 249), then one had better have a theory of such inequality and unfreedom.

\footnotetext{
${ }^{4}$ Things get worse. John Roemer (1994) has argued that the economic logic of exploitation allows for inputs other than labour (for example, corn, or oil) to be exploited. Which raises the question: why be interested in the exploitation of human by human? The answer can only appeal to something in the vicinity of moral value.

${ }^{5}$ Pace Allen Wood, Screpanti, and others, freedom is a moral good, one capable of justifying revolutionary action and not merely of explaining it. Communism, Screpanti says, represents the "workers' sentiments" and expresses their "aspiration in the form of a goal of political struggle" (98). What if there are no such sentiments? Does Screpanti think that, in the absence of revolutionary sentiment, revolution is unjustified or that capitalist exploitation is unobjectionable? No socialist can consistently sustain these apparent implications of Screpanti's views, widespread though they are.

${ }^{6}$ I am here in agreement with Screpanti. See Vrousalis (2020) where I enlist these ideas to criticize John Roemer's distributive critique of capitalism.
} 
If Screpanti is right, on the other hand, then the Critique of Political Economy amounts to no critique at all.

Sometimes Screpanti suggests that mere prudential considerations suffice to buttress his critique of capitalist exploitation. For example, he argues that capitalist private property evinces 'overwork', as workers only get access to the means of production after producing gratis surplus labour for the capitalists who own them. But, once again, 'overwork' entails a value judgment about acceptable levels of work. Crucially, according to Screpanti, the problem with capitalism is not that workers work too long or too hard, but rather that they cannot, themselves, determine that duration and intensity: "What really matters is the identification of the social subject who controls surplus labour" (11). Barring some argument for why alien control over the labour of others is unjustified, it remains a mystery why that really matters.

Despite these problems, Screpanti's book contains a lucid and succinct elaboration of Marx's theory of subsumption, to go along with a novel critical synthesis of Marx's theory of value. Screpanti's exegetical instincts are also right: a neglected but central aspect of Marx's critique of political economy has to do with the diverse ways in which capital comes to control, and therefore dominate, the labour of others.

\section{REFERENCES}

Cohen, Gerald A. 2000. If You're an Egalitarian, How Come You're So Rich?. Cambridge, MA: Harvard University Press.

Cohen, Joshua. 1989. “The Economic Basis of Deliberative Democracy.” Social Philosophy and Policy 6 (2): 25-50.

Geras, Norman. 1986. Literature of Revolution: Essays on Marxism. London: Verso.

Marx, Karl. 1973. Grundrisse: Foundations of the Critique of Political Economy (Rough Draft). Translated with a foreword by Martin Nicolaus. Harmondsworth: Penguin.

Marx, Karl. 1976. Capital: A Critique of Political Economy. Volume I. Translated by Ben Fowkes, with an introduction by Ernest Mandel. Harmondsworth: Penguin.

Marx, Karl. 1981. Capital: A Critique of Political Economy. Volume III. Translated by David Fernbach, with an introduction by Ernest Mandel. Harmondsworth: Penguin.

Marx, Karl, and Friedrich Engels. 1962. Werke (MEW). Band 32. Berlin: Dietz Verlag.

Marx, Karl, and Friedrich Engels. 2010. Collected Works (MECW). Vol. 35: Karl Marx Capital Volume I. New York, NY: Lawrence and Wishart.

Roemer, John E. 1994. Egalitarian Perspectives: Essays in Philosophical Economics. Cambridge: Cambridge University Press.

Skillman, Gilbert L. 2007. "Value Theory vs. Historical Analysis in Marx's Account of Capitalist Exploitation.” Science \& Society 71 (2): 203-226. 
Skillman, Gilbert L. 2019. "Marx's Economic Theory of Subsumption: Reclamation and Assessment.” Mimeo.

Vrousalis, Nicholas. 2018. "Capital without Wage-Labour: Marx's Modes of Subsumption Revisited.” Economics \& Philosophy 34 (3): 411-438.

Vrousalis, Nicholas. 2019. "Workplace Democracy Implies Economic Democracy.” Journal of Social Philosophy 50 (3): 259-279.

Vrousalis, Nicholas. 2020. "Socialism Unrevised: Against Roemer on Marx, Exploitation, Solidarity, Worker Control." Mimeo.

Wood, Allen W. 1972. "The Marxian Critique of Justice.” Philosophy \& Public Affairs 1 (3): 244-282.

Wood, Allen W. 2004. Karl Marx. $2^{\text {nd }}$ edition. London: Routledge.

Nicholas Vrousalis is Associate Professor in Practical Philosophy at Erasmus University Rotterdam. His main research areas are distributive ethics, theories of freedom, and Marxism. Vrousalis' work has appeared in Philosophy \& Public Affairs; The Journal of Ethics; Politics, Philosophy \& Economics; The Southern Journal of Philosophy, and Economics and Philosophy. His monograph The Political Philosophy of G. A. Cohen was published by Bloomsbury in 2015.

Contact e-mail: <vrousalis@esphil.eur.nl> 